Supporting Information

\title{
Simultaneous Sensing of Multiple Cancer Biomarkers by a Single DNA
}

\section{Nanoprobe in Nanopore}

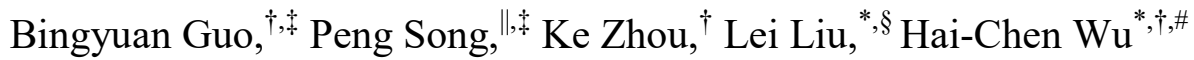

'Beijing National Laboratory for Molecular Sciences, Key Laboratory of Analytical Chemistry for Living Biosystems, Institute of Chemistry, Chinese Academy of Sciences, Beijing 100190, China

"Department of Geriatric Oncology, General Hospital of the Chinese People's Liberation Army, Beijing 100853, China

${ }^{\S}$ Key Laboratory for Biomedical Effects of Nanomaterials \& Nanosafety, Institute of High Energy Physics, Chinese Academy of Sciences, Beijing 100049, China

${ }^{\#}$ University of Chinese Academy of Sciences, Beijing 100049, China

These authors contributed equally to this work.

*To whom correspondence should be addressed. Email: haichenwu@iccas.ac.cn or leiliu@ihep.ac.cn

\section{Contents}

$\begin{array}{ll}\text { Supplementary Methods } & \text { S2 }\end{array}$

Supplementary Figure S1 S6

$\begin{array}{ll}\text { Supplementary Figure S2 } & \text { S7 }\end{array}$

$\begin{array}{ll}\text { Supplementary Figure S3 } & \text { S8 }\end{array}$

$\begin{array}{ll}\text { Supplementary Figure S4 S9 } & \text { S4 }\end{array}$

$\begin{array}{lr}\text { Supplementary Figure S5 } & \text { S10 }\end{array}$

$\begin{array}{ll}\text { Supplementary Figure S6 } & \text { S11 }\end{array}$

$\begin{array}{ll}\text { Supplementary Figure S7 } & \text { S12 }\end{array}$

Supplementary Table S1 S13-14

$\begin{array}{lr}\text { Supplementary Table S2 } & \text { S15 }\end{array}$

$\begin{array}{lr}\text { Supplementary Table S3 } & \text { S16 }\end{array}$

$\begin{array}{ll}\text { Supplementary References } & \text { S17-18 }\end{array}$ 


\section{Supplementary Methods}

\section{Materials and characterization.}

1,2-Diphytanoyl-sn-glycero-3-phosphocholine (DPhPc) was purchased from Avanti Polar Lipids (Alabaster, AL). All DNA and peptide samples were purified by HPLC and purchased from Sangon Biotechnology (Shanghai). Recombinant human MMP-9 protein (carrier free) and recombinant human $\mathrm{VEGF}_{121}$ protein (carrier free) were obtained from $\mathrm{R} \& \mathrm{D}$ Systems (Minneapolis, MN). Other protein samples were purchased from Abcam and Sigma-Aldrich. Micro Bio-Spin P6 gel columns (Tris buffer) were purchased from Bio-Rad (Hercules, CA). All the columns were pre-equilibrated three times with $80 \mu \mathrm{L}$ deionised water prior to use. All chemicals were purchased from Sigma-Aldrich, Alfa Aesar and J\&K, and used without further purification. Artificial urine was purchased from Beijing Biolab Science and Technology Co., Ltd. All DNA samples and buffers were prepared in deionised water (Millipore, MA). DNA concentration was measured on NanoDrop 2000C spectrophotometer. MALDI-TOF mass spectra were performed on BrukerAutoflex III. Circular dichroism spectra were obtained on JASCO J-810 spectrophotometer. DNA-peptide mixture separation was conducted on GE UPC-900 AKTA chromatograph equipped with Resource 15Q anion exchange column (USA). Wild type $\alpha$ HL-D8H6 proteins were produced as described previously. ${ }^{\mathrm{S} 1}$ In this work, the duration for all the MMP-9 catalytic reactions was set as $1 \mathrm{~h}$ to make the data consistent. Room temperature: $25 \pm 2^{\circ} \mathrm{C}$.

\section{Buffer preparation.}


$22.365 \mathrm{~g}$ of $\mathrm{KCl}(99.999 \%$, Sigma-Aldrich), $0.195 \mathrm{~g}$ of MES (99\%, Sigma-Aldrich) and 0.095 $\mathrm{g}$ of $\mathrm{MgCl}_{2}(99.9 \%$, Sigma-Aldrich) were dissolved in $80 \mathrm{~mL}$ of deionized water (Millipore, MA). $2 \mathrm{M} \mathrm{HCl}$ was used to adjust the $\mathrm{pH}$ to 5.0. The solution was diluted with deionized water to $100 \mathrm{~mL}$. The final buffer solution consists of $3 \mathrm{M} \mathrm{KCl}, 10 \mathrm{mM}$ MES and $10 \mathrm{mM} \mathrm{MgCl}_{2}$ at $\mathrm{pH}$ 5.0.

\section{Method for the preparation of DNA-peptide complexes.}

The conjugation between thiol-containing DNA and FGPLGLK peptide was carried out using thiol-maleimide click chemistry. $1.5 \mu \mathrm{L}$ tris(2-carboxyethyl)phosphine (TCEP, $200 \mathrm{mM}$, adjusted with ammonia to $\mathrm{pH}$ 7.4) was added to $100 \mu \mathrm{L}$ 5'-thiol-modified DNA (DNA4-6, 100 $\mu \mathrm{M})$. The mixture was rotated for $2 \mathrm{~h}$ at room temperature to reduce the oxidized thiols and washed with Micro Bio-spin P6 columns to remove the excessive TCEP. Then, maleimide-modified peptide $\left(N_{\text {term }}\right.$-FGPLGLK- $\left.C_{\text {term }}, 150 \mu \mathrm{L}, 1 \mathrm{mg} / \mathrm{mL}\right)$ was added to the filtrate, and ammonia was used to adjust $\mathrm{pH}$ to 9.4. The mixture was rotated for $4 \mathrm{~h}$ at room temperature. The separation of DNA-peptide mixture was conducted on Resource 15Q anion exchange column. Buffer A is $20 \mathrm{mM}$ Tris, $150 \mathrm{mM} \mathrm{NaCl}$, $\mathrm{pH}$ 8.0. Buffer $\mathrm{B}$ is $20 \mathrm{mM}$ Tris, 1 $\mathrm{M} \mathrm{NaCl}, \mathrm{pH}$ 8.0. After the sample was loaded on to the column, one column volume of Buffer A was used to wash the column. Then the gradient elution was conducted with buffer A and buffer B for 20 column volumes (from $100 \%$ A to $0 \%$ A). Two different fractions were separated and fraction 2 corresponded to peptide-modified DNA (DNA7-9).

\section{VEGF $_{121}$ detection experiments in the presence of $10 \mathrm{nM}$ MMP-9.}


DNA1 $(1.8 \mu \mathrm{L}, 111.1 \mu \mathrm{M})$ and DNA7 $(1.3 \mu \mathrm{L}, 153.8 \mu \mathrm{M})$ were added to $16.9 \mu \mathrm{L}$ incubation buffer and incubated for $2 \mathrm{~h}$ at room temperature to form the tMB nanoprobe. The total volume was $20 \mu \mathrm{L}$. After incubation, $\mathrm{CB}[7](5.0 \mu \mathrm{L}, 5.0 \mathrm{mM})$ was added and incubated for $2 \mathrm{~h}$. Next, the tMB nanoprobe was incubated with various concentrations of $\mathrm{VEGF}_{121}$ (final concentration: $0.1,1,10,30,50,70,100,140$ and $170 \mathrm{nM}$ ) and $10 \mathrm{nM}$ MMP-9 (final concentration) for $1 \mathrm{~h}$ at room temperature. The resulting solution was subjected to single channel recording experiments for the quantification of $\mathrm{VEGF}_{121}$ in the presence of $10 \mathrm{nM}$ MMP-9. After that, the solution was irradiated by $365 \mathrm{~nm}$ UV light for $10 \mathrm{~min}$ and another round of single channel recording experiments were conducted for the quantitative detection of $10 \mathrm{nM}$ MMP-9 in the presence of various concentrations of $\mathrm{VEGF}_{121}$.

\section{MMP-9 detection experiments in the presence of 10 nM VEGF $_{121}$.}

DNA1 $(1.8 \mu \mathrm{L}, 111.1 \mu \mathrm{M})$ and DNA7 $(1.3 \mu \mathrm{L}, 153.8 \mu \mathrm{M})$ were added to $16.9 \mu \mathrm{L}$ incubate buffer and incubated for $2 \mathrm{~h}$ at room temperature to form the tMB nanoprobe. The total volume was $20 \mu \mathrm{L}$. After incubation, $\mathrm{CB}[7](5.0 \mu \mathrm{L}, 5.0 \mathrm{mM})$ was added and incubated for 2 h. Next, the tMB nanoprobe was incubated with various concentrations of MMP-9 (final concentration: $0.01,0.1,1,10,30,50,70,90$ and $120 \mathrm{nM}$ ) and $10 \mathrm{nM} \operatorname{VEGF}_{121}$ (final concentration) for $1 \mathrm{~h}$ at room temperature. The resulting solution was subjected to single channel recording experiments for the quantitative detection of $10 \mathrm{nM} \mathrm{VEGF}_{121}$ in the presence of various concentrations of MMP-9. After that, the solution was irradiated by 365 nm UV light for $10 \mathrm{~min}$ and another round of single channel recording experiments were conducted for the detection of MMP-9 in the presence of $10 \mathrm{nM} \mathrm{VEGF}_{121}$. 
pH detection experiments in the presence of $10 \mathrm{nM} \mathrm{VEGF}_{121}$ and $10 \mathrm{nM}$ MMP-9.

DNA1 $(1.8 \mu \mathrm{L}, 111.1 \mu \mathrm{M})$ and DNA7 $(1.3 \mu \mathrm{L}, 153.8 \mu \mathrm{M})$ were added to $16.9 \mu \mathrm{L}$ incubate buffer and incubated for $2 \mathrm{~h}$ at room temperature to form the tMB nanoprobe. The total volume was $20 \mu \mathrm{L}$. After incubation, $\mathrm{CB}[7](5.0 \mu \mathrm{L}, 5.0 \mathrm{mM})$ was added and incubated for $2 \mathrm{~h}$. Next, the tMB nanoprobe was incubated with $10 \mathrm{nM} \mathrm{VEGF}_{121}$ and $10 \mathrm{nM}$ MMP-9 (both were final concentrations) for $1 \mathrm{~h}$ at room temperature. The resulting solution was added to the cis chamber which contained $1 \mathrm{~mL}$ buffer solution of $3 \mathrm{M} \mathrm{KCl}, 10 \mathrm{mM}$ phosphate, $10 \mathrm{mM} \mathrm{MgCl} 2$ with different $\mathrm{pH}(\mathrm{pH} 4,5,6,7,8)$. After the solution was thoroughly mixed, it was subjected to single channel recording experiments for measuring different solution $\mathrm{pH}$ values. 


\section{Supplementary Figures}
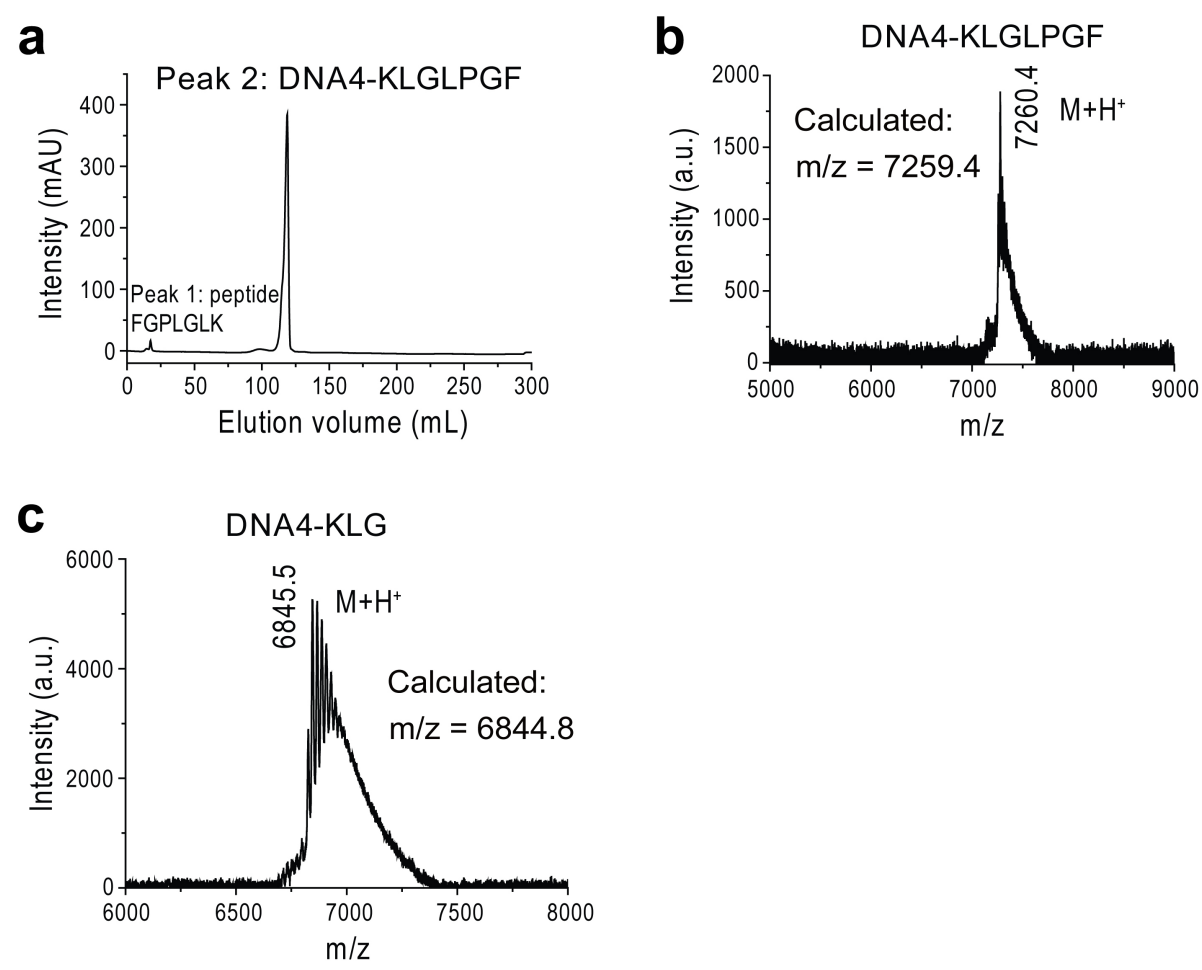

Figure S1. Syntheses and characterization of DNA-peptide hybrids. (a) Liquid chromatography showing the separation of DNA4-KLGLPGF and unreacted peptide. (b) Mass spectrometry characterization of DNA4-KLGLPGF. (c) Mass spectrometry characterization of DNA-KLG. 


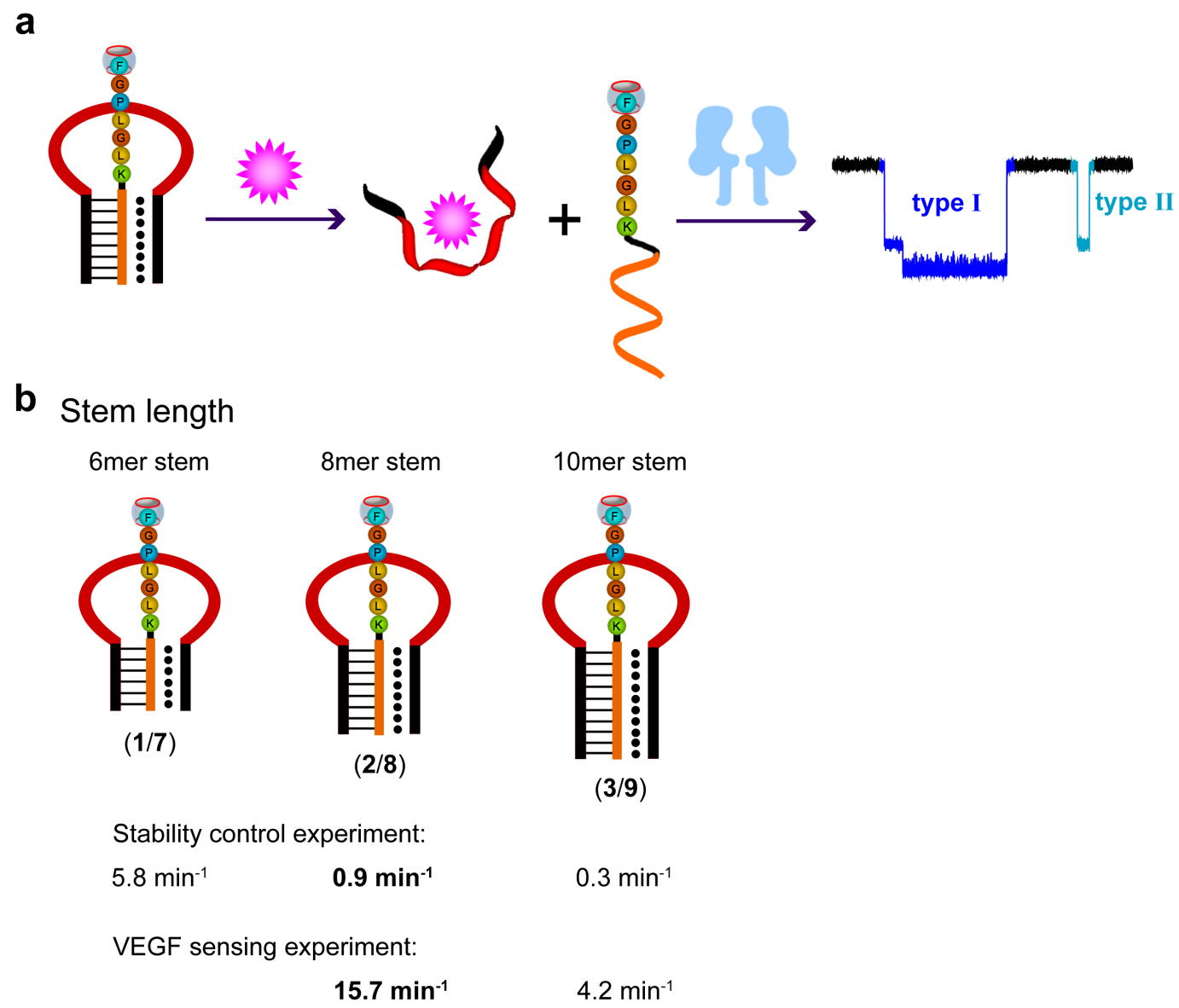

Figure S2. VEGF 121 sensing with the tMB nanoprobe. (a) Illustration of the sensing principle. Type I and type II events are indicated. (b) Optimization of the stem length of the tMB nanoprobe. All data were acquired in the buffer of $3 \mathrm{M} \mathrm{KCl}, 10 \mathrm{mM} \mathrm{MES,} 10 \mathrm{mM} \mathrm{MgCl}$, $\mathrm{pH}$ 5.0, with the transmembrane potential held at $+200 \mathrm{mV}$. Number of individual experiments $n=3$. 


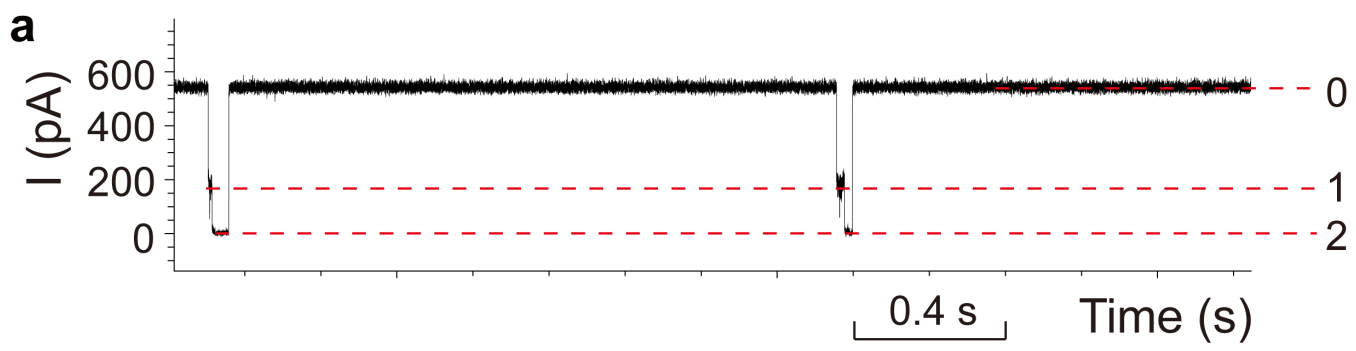

b

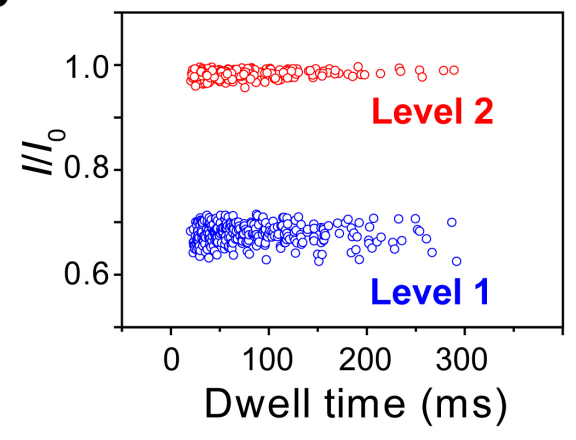

d

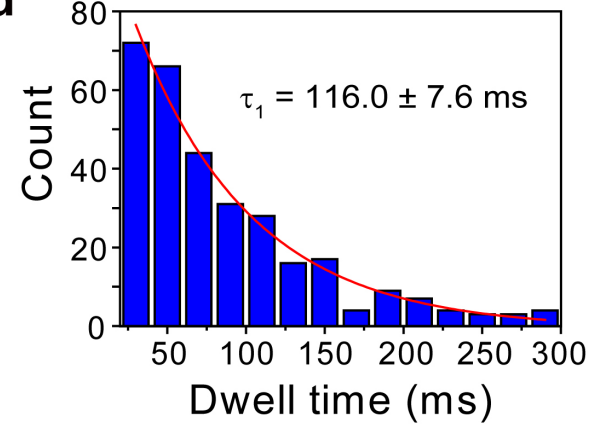

C

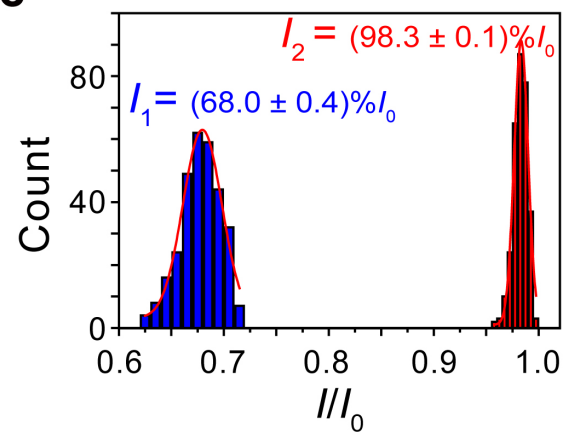

e

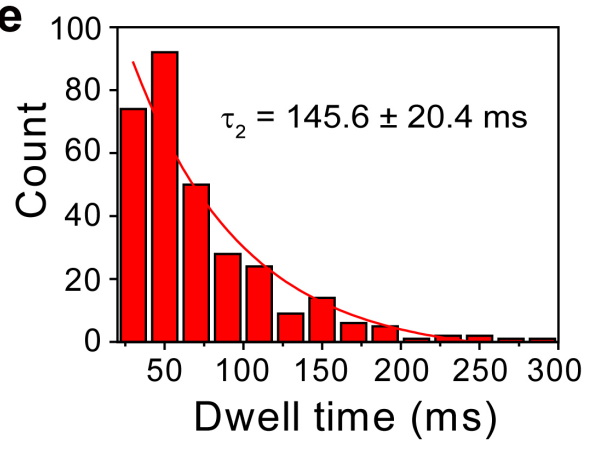

Figure S3. Characterization of current events generated by tMB nanoprobe in $\alpha \mathrm{HL}$. (a) A typical current trace generated by the tMB nanorpobe in $\alpha H L$. The events consist of two levels with the first one at around $68 \%$ of open pore current and the second one at almost full blockage. Level 0: open pore level; level 1: tMB trapped in the vestibule of $\alpha H L$; level 2: part of sfO enters the constriction of $\alpha \mathrm{HL}$. The frequency of the tMB event is $35.8 \pm 6.3$ $\min ^{-1}$. (b) Scatter plots showing current blockades versus event durations of level 1 and level 2. (c) Histograms of the current blockades of level 1 and level 2. The solid lines are Gaussian fit to the histograms. (d-e) Dwell time histograms of level 1 and level 2. The solid lines are single exponential fit to the histograms. The final concentration of tMB is $200 \mathrm{nM}$. All data were acquired in the buffer of $3 \mathrm{M} \mathrm{KCl}, 10 \mathrm{mM}$ MES, $10 \mathrm{mM} \mathrm{MgCl}_{2}, \mathrm{pH} 5.0$, with the transmembrane potential held at $+200 \mathrm{mV}$. Number of individual experiments $n=3$. 


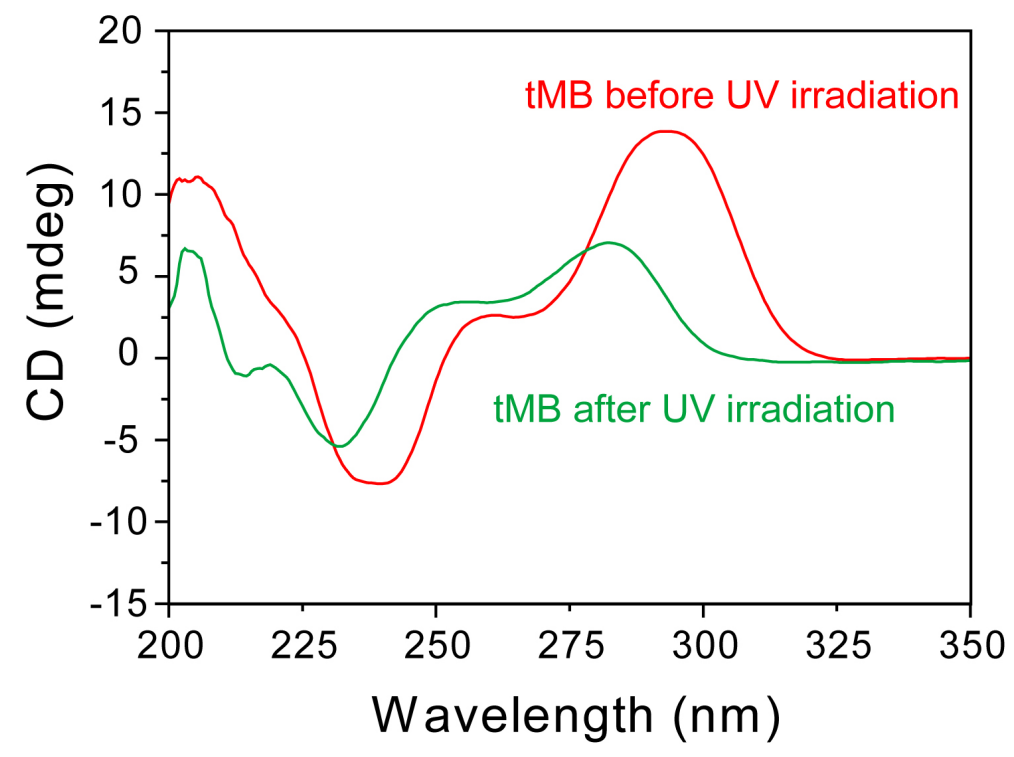

Figure S4. CD spectra of the tMB before (red) and after (green) $365 \mathrm{~nm}$ UV irradiation. The peak around $290 \mathrm{~nm}$ (red) represents the degree of base stacking in tMB. The $290 \mathrm{~nm}$ peak decreased and blue-shifted to $280 \mathrm{~nm}$ (green) after the $365 \mathrm{~nm}$ UV irradiation. 

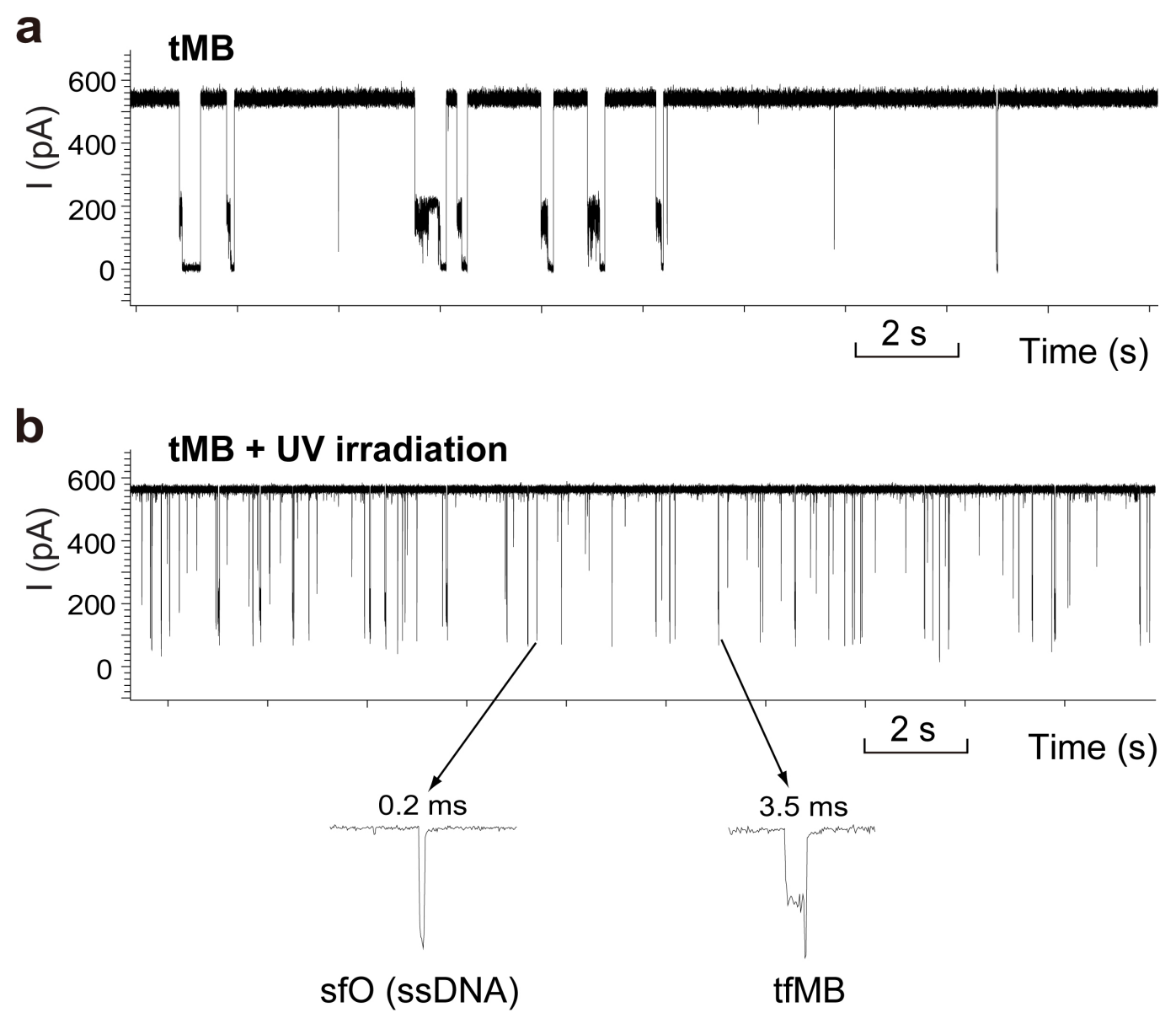

Figure S5. The effect of UV irradiation on the translocation of azobenzene-containing tMB through $\alpha$ HL. (a) A typical current trace generated by the tMB nanorpobe in $\alpha H L$. (b) The current trace generated by the tMB in $\alpha \mathrm{HL}$ after $365 \mathrm{~nm}$ UV irradiation. The arrows indicate the expanded views of two types of translocation events. The ssDNA events are produced by the sfO and the two-level events are produced by the tfMB. The final concentration of tMB is $200 \mathrm{nM}$. All data were acquired in the buffer of $3 \mathrm{M} \mathrm{KCl}, 10 \mathrm{mM} \mathrm{MES,} 10 \mathrm{mM} \mathrm{MgCl}_{2}, \mathrm{pH}$ 5.0 , with the transmembrane potential held at $+200 \mathrm{mV}$. Number of individual experiments $n$ $=3$. 

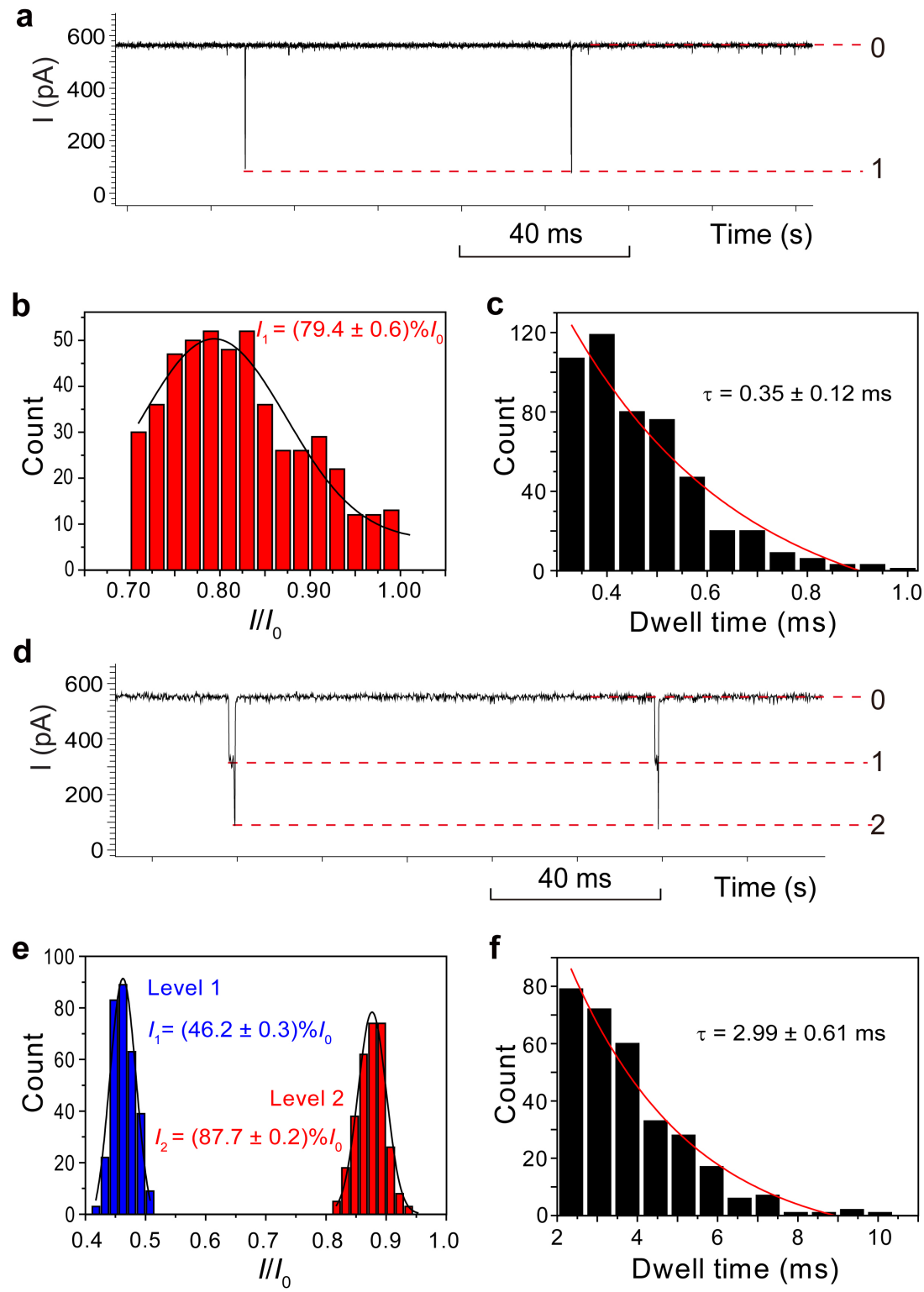

Figure S6. Characterization of current events generated by sfO and tfMB in $\alpha H L$. (a) A typical current trace generated by the translocation of sfO through $\alpha \mathrm{HL}$. The frequency of the tfMB event is $118.7 \pm 10.2 \mathrm{~min}^{-1}$. (b) Histograms of the current blockades of level 1 in $\mathbf{a}$. The solid line is Gaussian fit to the histograms. (c) Dwell time histograms of the events in a. The solid line is single exponential fit to the histograms. (d) A typical current trace generated by the translocation of tfMB through $\alpha H L$. The two-level pattern of the events is caused by the secondary structures of $\mathrm{VEGF}_{121}$ aptamer during translocation. Level 0: open pore level; level 1: tfMB entering the vestibule of $\alpha \mathrm{HL}$; level 2: unzipping of the tfMB secondary structure followed by translocation through $\alpha H L$. The frequency of the tfMB event is $63.1 \pm 7.8 \mathrm{~min}^{-1}$. (e) Histograms of the current blockades of level 1 and level 2 in $\mathbf{d}$. The solid lines are Gaussian fit to the histograms. (f) Dwell time histograms of the events in $\mathbf{d}$. The solid line is single exponential fit to the histograms. All data were acquired in the buffer of $3 \mathrm{M} \mathrm{KCl}, 10$ $\mathrm{mM}$ MES, $10 \mathrm{mM} \mathrm{MgCl}_{2}$, pH 5.0, with the transmembrane potential held at $+200 \mathrm{mV}$. 


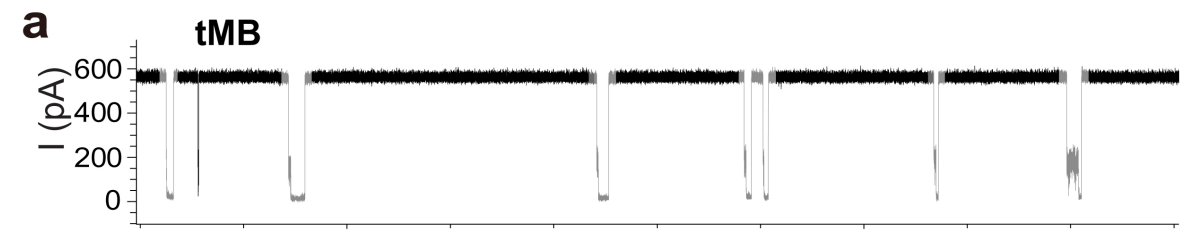

b

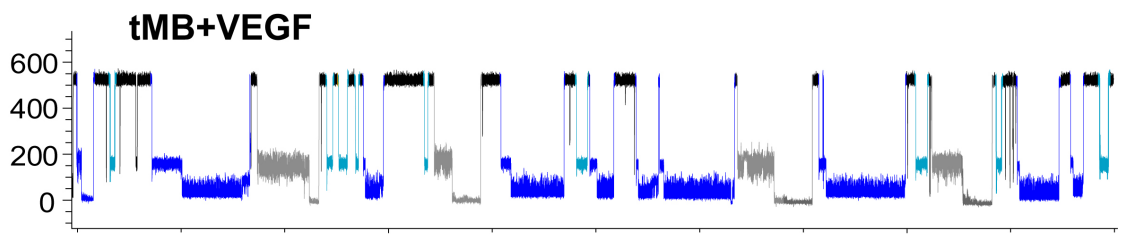

C

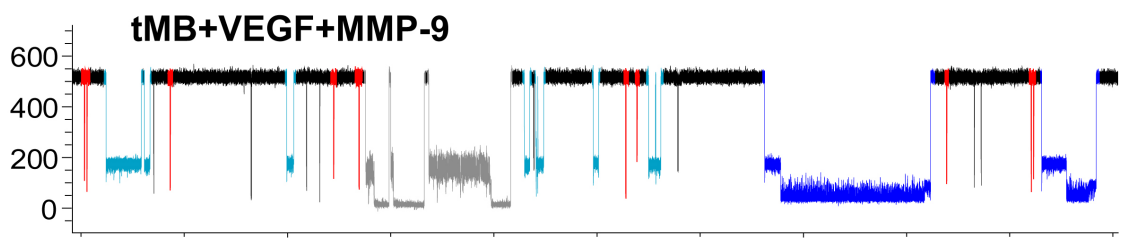

d

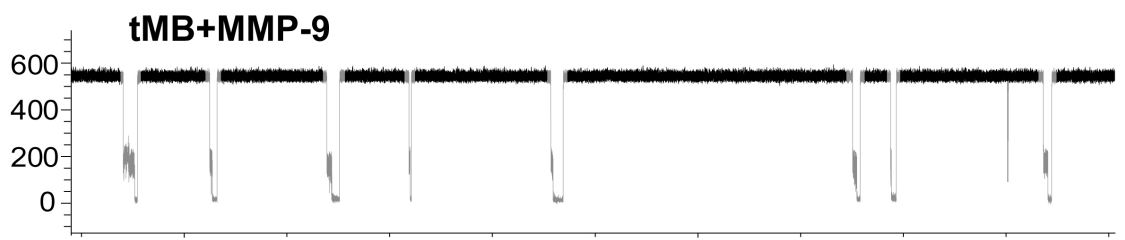

e

tMB+MMP-9+VEGF

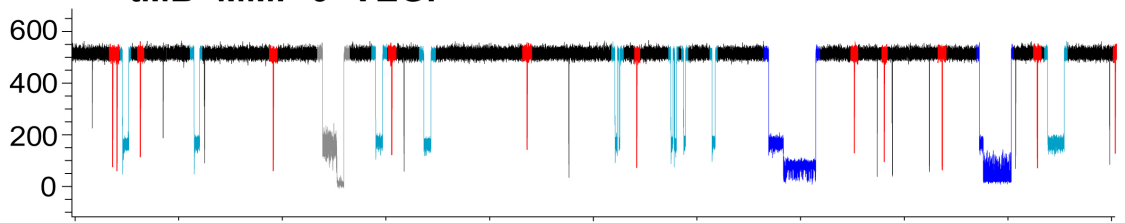

f

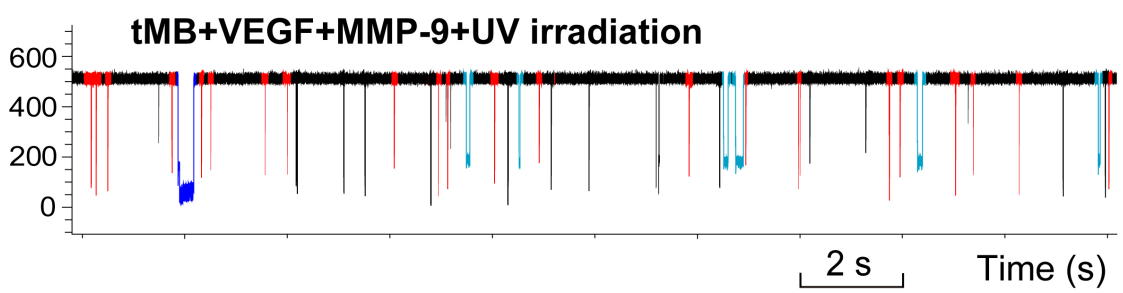

Figure S7. Sequential detection of $\mathrm{VEGF}_{121}$ and MMP-9. Typical traces show the current events produced by the sequential presence of (a) $200 \mathrm{nM}$ tMB nanoprobe; (b) $200 \mathrm{nM}$ tMB + $30 \mathrm{nM} \mathrm{VEGF}_{121}$; (c) $200 \mathrm{nM}$ tMB + $30 \mathrm{nM} \mathrm{VEGF}_{121}+30 \mathrm{nM}$ MMP-9; (d) $200 \mathrm{nM}$ tMB + 30 nM MMP-9; (e) 200 nM tMB + 30 nM MMP-9 + 30 nM VEGF 121 ; (f) $200 \mathrm{nM}$ tMB + $30 \mathrm{nM}$ MMP-9 + $30 \mathrm{nM} \mathrm{VEGF}_{121}+\mathrm{UV}$ irradiation. The color coding is as follows: grey represents the events caused by tMB nanoprobe; blue represents type I events; cyan represents type II events; red represents ssDNA translocation events; black represents tfMB translocation events. The detailed experimental procedures are described in the Experimental Section. All data were acquired in the buffer of $3 \mathrm{M} \mathrm{KCl}, 10 \mathrm{mM}$ MES, $10 \mathrm{mM} \mathrm{MgCl}_{2}, \mathrm{pH} 5.0$, with the transmembrane potential held at $+200 \mathrm{mV}$. 


\section{Supplementary Tables}

Table S1. Sequences of DNA probes in this study.

\begin{tabular}{|c|c|c|}
\hline Name & Sequence & Modification \\
\hline DNA1 & $\begin{array}{l}\text { 5'-TCTC/Azo/TCTCCAGCTGTCTATGAGAAA } \\
\text { ATCATCCATACGGCTCTCTCT-3' }\end{array}$ & Azo modification \\
\hline DNA2 & $\begin{array}{l}\text { 5'-TCT/Azo/CTCCAGCTGTCTATGAGAAAAT } \\
\text { CATCCATACGGCTCTCT-3' }\end{array}$ & Azo modification \\
\hline DNA3 & $\begin{array}{l}\text { 5'-ТСТCТ/Azo/CTCTCCAGCTGTCTATGAGA } \\
\text { AAATCATCCATACGGCTCTCTCTCT-3' }\end{array}$ & Azo modification \\
\hline DNA4 & 5'-TCAATTACAAATGAGAGAGA-3' & 5'-thiol modification \\
\hline DNA5 & 5'-TCAATTACAAATCTGAGAGA-3' & 5'-thiol modification \\
\hline DNA6 & 5'-TCAATTACAAGAGAGAGAGA-3' & 5'-thiol modification \\
\hline DNA7 & 5'-TCAATTACAAATGAGAGAGA-3' & $\begin{array}{l}\text { 5'-FGPLGLK peptide } \\
\text { modification }\end{array}$ \\
\hline DNA8 & 5'-TCAATTACAAATCTGAGAGA-3' & $\begin{array}{l}\text { 5'-FGPLGLK peptide } \\
\text { modification }\end{array}$ \\
\hline DNA9 & 5'-TCAATTACAAGAGAGAGAGA-3' & $\begin{array}{l}\text { 5'-FGPLGLK peptide } \\
\text { modification }\end{array}$ \\
\hline DNA10 & 5'-TCAATTACAAATGAGAGAGA-3' & $\begin{array}{l}\text { 5'-GLK peptide } \\
\text { modification }\end{array}$ \\
\hline
\end{tabular}

Note: all the loop sequences are in bold; all the stem sequences are underlined; the modified site on DNA is marked in red.

5'-thiol modification<smiles>O=P(O)(O)OCCCCCS</smiles> 
5'-FGPLGLK peptide $\left(N_{\text {term }}\right.$-FGPLGLK- $\left.C_{\text {term }}\right)$ modification

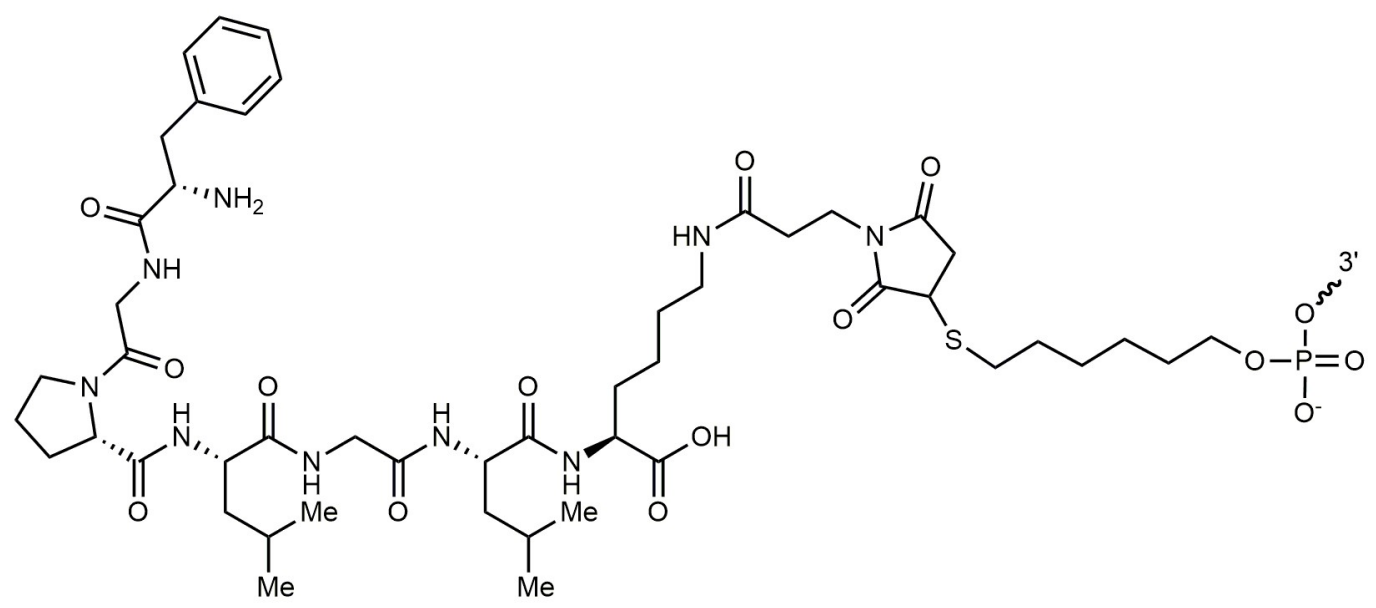

5'-GLK peptide $\left(N_{\text {term }}\right.$-GLK- $\left.C_{\text {term }}\right)$ modification<smiles>COP(=O)(O)OCCCCCCSC1CC(=O)N(CCC(=O)NCCCC[C@H](NC(=O)[C@H](CC(C)C)NC(=O)CN)C(=O)O)C1=O</smiles>

Azo modification

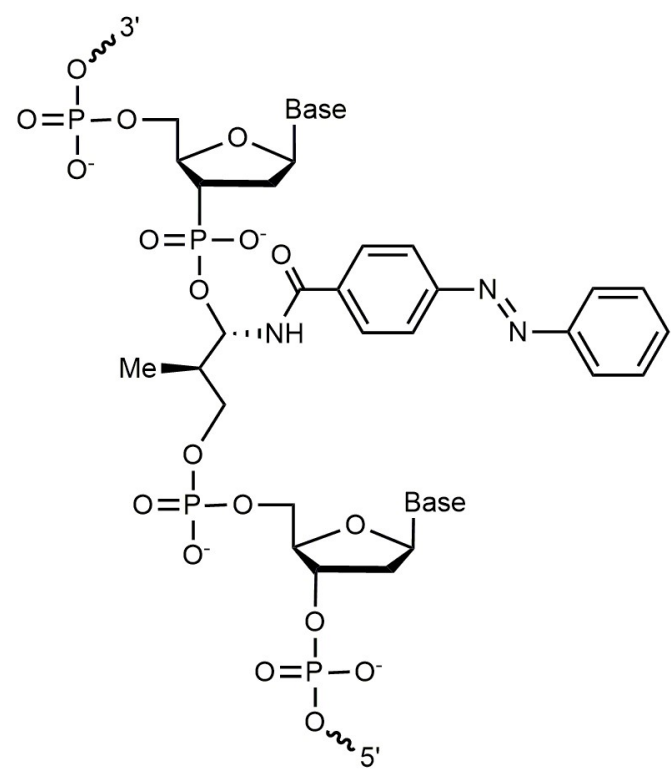


Table S2. Comparison of LOD with literature methods for the detection of VEGF $\mathrm{V}_{121}$.

\begin{tabular}{ccc}
\hline Methods & Limit of detection & Reference \\
\hline surface plasmon resonance & $7.1 \mathrm{pM}$ & {$[2]$} \\
Screen-printed electrode & $5 \mathrm{pM}$ & {$[3]$} \\
$\begin{array}{c}\text { Electrochemical impedance } \\
\text { spectroscopy }\end{array}$ & $89.3 \mathrm{pM}$ & {$[4]$} \\
Electrochemical immunosensor & $0.26 \mathrm{nM}$ & {$[5]$} \\
Microarray & $0.1 \mathrm{nM}$ & {$[6]$} \\
Surface-enhanced Raman scattering & $0.07 \mathrm{pM}$ & {$[7]$} \\
Fluorescence & $0.5 \mathrm{nM}$ & {$[8]$} \\
Nanopore & $0.1 \mathrm{nM}$ & This work
\end{tabular}


Table S3. Comparison of LOD with literature methods for the detection of MMP-9.

\begin{tabular}{ccc}
\hline Methods & Limit of detection & Reference \\
\hline $\begin{array}{c}\text { Electrochemical Impedance } \\
\text { Spectroscopy }\end{array}$ & $1.3 \mathrm{nM}$ & {$[9]$} \\
Surface-enhanced Raman scattering & $0.1 \mathrm{pM}$ & {$[10]$} \\
Reflectivity spectrum & $100 \mathrm{nM}$ & {$[11]$} \\
Quartz crystal microbalance & $7.3 \mathrm{pM}$ & {$[12]$} \\
ELISA & $4.3 \mathrm{pM}$ & {$[13]$} \\
Colorimetry & $0.14 \mathrm{pM}$ & {$[14]$} \\
Cyclic voltammetry & $7 \mathrm{pM}$ & {$[15]$} \\
Nanopore & $10 \mathrm{pM}$ & This work \\
\hline
\end{tabular}




\section{Supplementary References}

(1) Wen, S.; Zeng, T.; Liu, L.; Zhao, K.; Zhao, Y.; Liu, X.; Wu, H.-C., Highly Sensitive and Selective DNA-Based Detection of Mercury(II) with alpha-Hemolysin Nanopore. J. Am. Chem. Soc. 2011, 133, 18312-18317.

(2) Chen, H.; Hou, Y.; Qi, F.; Zhang, J.; Koh, K.; Shen, Z.; Li, G., Detection of vascular endothelial growth factor based on rolling circle amplification as a means of signal enhancement in surface plasmon resonance. Biosens. Bioelectron. 2014, 61, 83-87.

(3) Zhao, S.; Yang, W.; Lai, R. Y., A folding-based electrochemical aptasensor for detection of vascular endothelial growth factor in human whole blood. Biosens. Bioelectron. 2011, $26,2442-2447$.

(4) Kalyoncu, D.; Tepeli, Y.; Kirgöz, U. C.; Buyraç, A.; Anik, Ü., Electro-nano diagnostic platforms for simultaneous detection of multiple cancer biomarkers. Electroanal. 2017, 29, 2832-2838.

(5) Pan, L. H.; Kuo, S. H.; Lin, T. Y.; Lin, C. W.; Fang, P. Y.; Yang, H. W., An electrochemical biosensor to simultaneously detect VEGF and PSA for early prostate cancer diagnosis based on graphene oxide/ssDNA/PLLA nanoparticles. Biosens. Bioelectron. 2017, 89, 598-605.

(6) Kurth, T.; Witt, S.; Bolten, S.; Waniek, J. J.; Kortmann, C.; Lavrentieva, A.; Scheper, T.; Walter, J. G., Development of aptamer-based TID assays using thermophoresis and microarrays. Biosens. 2019, 9, 124.

(7) Ko, J.; Lee, S.; Lee, E. K.; Chang, S. I.; Chen, L.; Yoon, S. Y.; Choo, J., SERS-based immunoassay of tumor marker VEGF using DNA aptamers and silica-encapsulated hollow gold nanospheres. Phys. Chem. Chem. Phys. 2013, 15, 5379-5385.

(8) Wang, S.-E.; Huang, Y.; Hu, K.; Tian, J.; Zhao, S., A highly sensitive and selective aptasensor based on fluorescence polarization for the rapid determination of oncoprotein vascular endothelial growth factor (VEGF). Anal. Methods 2014, 6, 62-66.

(9) Ciani, I.; Schulze, H.; Corrigan, D. K.; Henihan, G.; Giraud, G.; Terry, J. G.; Walton, A. J.; Pethig, R.; Ghazal, P.; Crain, J.; Campbell, C. J.; Bachmann, T. T.; Mount, A. R., Development of immunosensors for direct detection of three wound infection biomarkers 
at point of care using electrochemical impedance spectroscopy. Biosens. Bioelectron. 2012, 31, 413-418.

(10) Mohseni, S.; Moghadam, T. T.; Dabirmanesh, B.; Jabbari, S.; Khajeh, K., Development of a label-free SPR sensor for detection of matrixmetalloproteinase-9 by antibody immobilization on carboxymethyldextran chip. Biosens. Bioelectron. 2016, 81, 510-516.

(11) Soeriyadi, A. H.; Gupta, B.; Reece, P. J.; Gooding, J. J., Optimising the enzyme response of a porous silicon photonic crystal via the modular design of enzyme sensitive polymers. Polym. Chem. 2014, 5, 2333-2341.

(12) Scarano, S.; Dausse, E.; Crispo, F.; Toulme, J. J.; Minunni, M., Design of a dual aptamer-based recognition strategy for human matrix metalloproteinase 9 protein by piezoelectric biosensors. Anal. Chim. Acta 2015, 897, 1-9.

(13) Barascuk, N.; Veidal, S. S.; Larsen, L.; Larsen, D. V.; Larsen, M. R.; Wang, J.; Zheng, Q.; Xing, R.; Cao, Y.; Rasmussen, L. M.; Karsdal, M. A., A novel assay for extracellular matrix remodeling associated with liver fibrosis: An enzyme-linked immunosorbent assay (ELISA) for a MMP-9 proteolytically revealed neo-epitope of type III collagen. Clin. Biochem. 2010, 43, 899-904.

(14) Ben Ismail, M.; de la Serna, E.; Ruiz-Vega, G.; Garcia-Berrocoso, T.; Montaner, J.; Zourob, M.; Othmane, A.; Baldrich, E., Using magnetic beads and signal amplifiers to produce short and simple immunoassays: Application to MMP-9 detection in plasma samples. Anal. Chim. Acta 2018, 999, 144-154.

(15) Lee, J.; Yun, J. Y.; Lee, W. C.; Choi, S.; Lim, J.; Jeong, H.; Shin, D.-S.; Park, Y. J., A reference electrode-free electrochemical biosensor for detecting MMP-9 using a concentric electrode device. Sensor. Actuat. B-Chem. 2017, 240, 735-741. 